\title{
What does not kill us makes us stronger: the story of repetitive consumer loan applications.
}

CAGLAYAN, M., TALAVERA, O., XIONG, L. and ZHANG, J. 


\title{
What does not kill us makes us stronger: The story of repetitive consumer loan applications*
}

\author{
Mustafa Caglayan ${ }^{\mathrm{a}}$, Oleksandr Talavera ${ }^{\mathrm{b}}$, Lin Xiong ${ }^{\mathrm{c}}$, Jing Zhang ${ }^{\mathrm{d}}$
}

This version: 23 July 2020

\begin{abstract}
We investigate borrower and lender behaviours when the borrower has experienced a sequence of failed loan applications. Our analysis is based on half a million observations from an established peer-to-peer (P2P) loan platform in China from 2010-2018. We find that borrowers who have better credit scores and who accept to pay higher interest rates are likely to reapply for funds after experiencing an earlier failed attempt. However, females and applicants with more education are discouraged from re-applying compared to their male or less-educated counterparts, respectively. On the funding supply side, lenders strive to fund safe borrowers who have high credit ratings and high income, though not those who offer a high interest rate.
\end{abstract}

Keywords: Peer-to-peer (P2P) lending; Discouraged borrower; Loan listing outcomes; Fintech; China.

JEL classification: G14, G32, M10

*Standard disclaimer applies. This research is supported by Economic and Social Research Council (ESRC) grant ES/P004741/1. We are grateful to Haofeng Xu for excellent research assistance. In memory of Professor Josephine Maltby (1954-2017).

a School of Management and Languages, Heriot-Watt University, Edinburgh EH14 4AS, United Kingdom. Email: m.caglayan@hw.ac.uk

b Department of Economics, Birmingham Business School, University of Birmingham, Birmingham B15 2TT, United Kingdom. Email: oleksandr.talavera@gmail.com

${ }^{c}$ Corresponding author, Aberdeen Business School, Robert Gordon University, Aberdeen AB10 7QE, United Kingdom. Email: 1.xiong@rgu.ac.uk

d College of Management and Economics, Tianjin University No.92 Weijin Road, Nankai District, Tianjin, China. Email: zhangjing6523@tju.edu.cn 
What does not kill us makes us stronger: The story of repetitive consumer loan applications*

\begin{abstract}
We investigate borrower and lender behaviours when the borrower has experienced a sequence of failed loan applications. Our analysis is based on half a million observations from an established peer-to-peer (P2P) loan platform in China from 2010-2018. We find that borrowers who have better credit scores and who accept to pay higher interest rates are likely to reapply for funds after experiencing an earlier failed attempt. However, females and applicants with more education are discouraged from re-applying compared to their male or less-educated counterparts, respectively. On the funding supply side, lenders strive to fund safe borrowers who have high credit ratings and high income, though not those who offer a high interest rate. Keywords: Peer-to-peer (P2P) lending; Discouraged borrower; Loan listing outcomes; Fintech; China.

JEL classification: G14, G32, M10
\end{abstract}




\section{Introduction}

Often, both companies and individuals require external sources of finance to adjust their investment and consumption expenditures. Although economic agents can use a variety of financial products to time their consumption, it is arguable whether an ordinary person could overcome credit constraints caused by price or non-price barriers (Kempson et al., 2004; Sarma and Pais, 2011; Allen et al., 2016). In this context, financial inclusion continues to be an important challenge that requires the attention of financial regulators. Not surprisingly, several researchers have examined the merits of financial inclusiveness. Inclusive financial systems not only enable the efficient allocation of resources and reduce the cost of funding but also promote investment in education and the development of better risk management practices (Dupas and Robinson, 2013; Bruhn and Love, 2014). As a result, countries with inclusive financial systems can expect to achieve higher economic growth, resist the impact of negative shocks, and enjoy improvements in societal welfare.

Over the last decade, substantial increases in the use of the internet, often due to the rapid penetration of mobile devices in emerging economies, have reduced the cost of providing financial services to those living in areas with limited access to bank branches. Furthermore, the emergence of online peer-to-peer (P2P) lending platforms has provided policymakers with a new and powerful tool through which to improve financial inclusion, as anyone with a digital device and a web presence can easily engage in transactions on a P2P platform to lend or to raise funds. For instance, to seek funds through a P2P platform, a borrower must simply submit a funding application and provide information about the amount of funding needed, his/her personal attributes, and a narrative for the requested loan. In return, funders (the crowd), unlike traditional financial institutions, make their funding decisions after they examine the funding application - sometimes even without interacting with the applicant.

Given their efficiency, P2P platforms can play a pivotal role in the raising of funds at an affordable cost by those people who are excluded from traditional financial institutions. However, while a person may be in need of additional funds and has access to an online platform, it is possible that this individual may decide to not submit a new funding request if she has had a negative experience on that P2P platform. That is, an applicant, despite being financially constrained, may be discouraged from posting a new listing to a P2P platform if she has experienced one or more rejections on an earlier P2P loan application.

The literature presents a long trail of academic research on credit-constrained consumers. A 
consumer is considered to be credit-constrained if she had either been turned down for credit or been unable to borrow the full amount she wished from lenders (Jappelli, 1990; Crook, 1999; Johnson and Li, 2010). Many of the existing studies and policy initiatives reflect the notion that financially constrained consumers experience difficulty in gaining access to credit and obtaining an adequate level of financing. Equally, a consumer who considered applying for credit but who did not apply because she believed that she would be turned down is also creditconstrained. Such a consumer would be called a discouraged borrower. However, there has been limited investigation of discouraged borrowers, as discouragement is largely unobservable and its examination depends on survey data. Based on household survey data, Lyons (2003) and Attanasio et al. (2008) argued that age, education, marital status, gender, household size, income, and net wealth play important roles in determining an individual's access to funds for household consumption expenditures. More recently, also focusing on survey data, Freel et al. (2012) argued that the scale of discouraged borrowers is twice as large as that of rejected borrowers. Naturally, these observations have led politicians to interfere with the market to support discouraged borrowers, as credit constraints affect the problem of resource allocation as well as the impact of policy measures.

This paper seeks to contribute to the emerging literature on the supply- and demand-side problems that borrowers face in raising credit to support their consumption expenditures (Ferrando and Mulier, 2015; Rostamkalaei et al., 2018). In doing so, we strive to examine the behaviour of discouraged borrowers and the factors that lenders consider in the lending decision process. Yet, there are important differences between the previous works and our study. In our paper, rather than using survey-based or self-reported data, as the extant literature has done, we examine P2P loan applications and define discouraged borrower as an individual who does not submit a new loan application after having experienced one or more loan request rejections. Hence, our definition is based on observed behaviour and, therefore, differs from the survey-based research. Our approach allows us to estimate the likelihood that an applicant will submit a new loan request and to scrutinize which loan-specific and individual-specific factors would discourage applicants from posting a new funding request. Separately, examining data from the lenders' perspective, we seek to understand lenders' reaction to an applicant who submits a new loan request after a failed round. Having examined both the supply and demand sides of the problem, we then make several suggestions to address the problem of borrower discouragement.

We pursue our investigation by employing a unique dataset collected from Renrendai.com, a 
leading Chinese peer-to-peer (P2P) loan platform. Throughout the past decade, the Chinese P2P loan sector faced rapid growth and the number of digital intermediaries skyrocketed to the level of several thousand companies. Over this short period of time, the liberal regulatory framework that China maintains with respect to these institutions led China to become the largest crowdlending market in the world. At the same time, similar to the situation in many other emerging countries, access to formal lending in China is quite restricted and consumers and firms rely heavily on informal or shadow lending. ${ }^{1}$ These unique features make Chinese data useful and appropriate for studying the behaviour of discouraged borrowers as well as of small investors who offer loans through digitalized lending platforms.

Crowdlending financial intermediaries have several unique aspects that set them apart from the traditional financing sector. First, P2P loan platforms are likely to be more efficient than the traditional financing route (for instance, banks), as they offer a direct link between lenders and borrowers. In theory, the entire process - from application to funding - takes, at most, seven days. Second, the application costs in this environment are low; there is no need for borrowers to visit a bank branch to fill in forms or to communicate with a financial adviser. Third, the sample size is large: we record applicants' funding requests and the subsequent outcomes of the applications. We also collect information about listing and borrower characteristics for all applications. Hence, the dataset allows us to examine the factors that affect the likelihood of the approval/rejection of funding requests, which gives us a basis upon which to hypothesize why certain applicants are discouraged from engaging with the market.

Our data reveal that discouraged borrowers outnumber rejected borrowers - a result in line with those of a number of previous studies (e.g., Cole and Sokolyk, 2016). We then draw a profile of discouraged borrowers based on the observation that they do not submit new applications for new loans after one or more earlier turndowns. ${ }^{2}$ In particular, repeat applicants have better credit scores and are prepared to pay higher interest rates to obtain a loan as compared to their discouraged peers. We also document that female borrowers drop out of the loan market earlier than do males after experiencing a failed funding application. Notably, less-educated applicants are more likely to reapply after experiencing a rejection. ${ }^{3}$ Furthermore, loan narratives get

\footnotetext{
${ }^{1}$ E.g., see FT.com https://www.ft.com/content/4c66b622-dea5-11e9-9743-db5a370481bc, accessed 25.01.2020.

2 The impact of previous loan application turndowns has not been considered in the discouraged borrower literature except for Rostamkalaei et al. (2018), who examined the effects of informal turndowns.

${ }^{3}$ Educated applicants are expected to have better incomes in the future and can postpone their financial needs rather than borrowing a loan that will require them to pay high interest rates.
} 
shorter as individuals reapply for credit. While this might be interpreted as indicating that borrowers sharpen their reasoning to borrow funds, we also provide evidence that investors (i.e., lenders) do not take narratives into account when they make funding decisions. Finally, we show that applicants from large cities tend to be discouraged from applying for funds.

When we examine lenders' behaviour, we immediately see that they strive to fund safe borrowers; both the credit rating and the income of the borrower play a major role in determining lenders' decisions to invest. Furthermore, lenders do not seek higher interest on funds, which suggests that they prefer to finance low-risk borrowers who are likely to pay back the loan in full. That is, investors do not finance risky borrowers who are willing to pay higher rates. Secondly, we find that lenders prefer to fund small-size loan requests with a longer term to maturity. Thirdly, we see that investors fund applicants who have longer work histories. Finally, and importantly, we do not find any evidence of gender- or location-based discrimination from the perspective of lenders.

The rest of this paper is organized as follows. Section 2 lays out a brief literature review. Section 3 provides information about the peer-to-peer industry in China and our data source, the Renrendai.com platform. This section also discusses basic sample statistics and empirical strategy. Section 4 discusses the empirical results. Section 5 concludes and provides implications.

\section{A quick look at the discouraged borrower problem and our approach}

Researchers and policymakers have recognized the presence of discouraged borrowers. In examining discouraged borrowers, empirical researchers have taken a direct approach and used survey data to identify the factors that affect discouragement. Jappelli (1990) argued that the omission of discouraged consumers from the data may lead to a biased estimation of the probability that consumers are credit-constrained and that about $19 \%$ of the surveyed families were, indeed, credit-constrained. Similarly, Lyons (2003) stated that, in considering the demographic characteristics and financial portfolios of discouraged consumers, one can observe that discouraged consumers are far more constrained than are those whose loan requests were rejected. Specifically, research has shown that non-white households, households with a female head, single females, and borrowers with previous repayment failures are substantially discouraged from applying for consumer loans (e.g., Hawley and Fujii, 
1990). ${ }^{4}$ The basic message of this research is that, for discouraged borrowers, having some access to credit lines is important, as the availability of credit can help them improve the timing of their consumption expenditures (e.g., Bergstresser, 2010).

More recently, economic agents began to use online lending platforms to smooth out their consumption pattern. Indeed, it has been recognized that P2P platforms can help increase financial inclusion by offering a means to raise funds relatively quickly and at a reasonable cost. Furthermore, applicants are not challenged by geographical barriers, due to the use of online platforms in raising credit. ${ }^{5}$ In fact, consumers or small businesses that traditional financial institutions consider too risky in terms of extending loans can raise funds through P2P platforms more easily to time their consumption expenditures. ${ }^{6}$ To that end, researchers argue that individual lenders, whose approach to lending differs from the discriminatory practices of financial institutions, lend more fairly to consumers through the use of P2P platforms (e.g., Herzenstein et al., 2008).

In this paper, unlike the earlier studies, which used survey data to examine discouraged borrowers, we follow P2P loan applicants' behaviour - a natural experiment-for up to three consecutive failed loan requests. In particular, we consider the extent to which loan- and borrower-specific factors discourage consumers from applying for funds. In our investigation, we take a close look at the listing and individual characteristics of those applicants whose loan requests are approved so that we can understand the factors that affect investors' lending behaviour. Hence, by examining the funding problem from the viewpoint of both the lenders and the borrowers, we can highlight the aspects that policymakers should target to reduce borrower discouragement.

\section{Data and empirical strategy}

\subsection{P2P loan data from Renrendai.com}

To conduct this study, we collected data from Renrendai.com. This platform is one of the largest and fastest-growing P2P platforms in China. Using this platform, the potential borrower can seek any amount ranging from 3,000 to 500,000 RMB (appr. from 400 to 70,000 USD). ${ }^{7}$

\footnotetext{
${ }^{4}$ Similarly, Crook (1999), using US Consumer Finance survey data, provided evidence that minorities and single females are more likely to be discouraged from applying for loans.

${ }^{5}$ See, for instance, Kim and Moor (2017).

${ }^{6}$ Along these lines, see De Roure et al. (2016).

${ }^{7}$ See Caglayan et al. (2019) or Gao et al. (2020) for more detailed information about the dataset.
} 
The platform was founded in October 2010 and has the largest number of registered members for P2P lending. As of the end of October 2018, it had facilitated over 73.4 billion RMB (appr. 10.4 billion USD) in loans. Renrendai was rated as aAA (the highest level) online lending platform by the Chinese Academy of Social Science and the Chinese Fintech Association in 2014 and 2015. The sample we examine contains information about 600,000 borrower listings posted on the platform between October 2010 and October 2018.

To seek a loan on Renrendai.com, an applicant must first create a listing and specify the amount of funding required. There is no fee for posting a listing. In setting it up, the borrower must upload a written statement to describe the purpose of the loan, provide information about whether she owns any vehicles, and provide personal information, including age, education, gender, employment, and marital status. Upon receiving this information, the platform gives a credit score to each borrower based on the submitted information and the borrower's earlier transactions with Renrendai.com, e.g., the number of repaid and being-repaid loans, default history, and amount of outstanding credit.

In collecting the data, we track each listing over time and record whether or not it is filled, as well as its repayment status. Once a listing is posted, it is displayed on the platform for up to seven days. If the application is filled, the borrower receives and uses the full amount requested from the platform. Otherwise, the committed funds are returned to the investors. For each listing, we download all available information about loan characteristics, e.g., loan amount, interest rate, term, listing time, and loan narrative as well as borrower characteristics. We also keep track of the number of times an applicant has posted a funding request (listing) on the platform.

\section{Please insert Table 1 about here}

Table 1 provides a basic summary of statistics concerning all loan requests in the data. We see that the average loan amount is about 52,000 RMB (appr. 7,520 USD), with a substantial standard deviation, implying that some individuals seek either a lot more or a lot less than the average. The average interest rate is approximately $13.5 \%$. While the platform allows borrowers to choose any term between three months and three years, with an increment of three months, the average loan term is 18 months. All loans are uncollateralised and come with a loan narrative that contains, on average, 47 words. Given the standard deviation of this category (36), it is clear that some borrowers are very parsimonious in expressing their intentions for the funds, while others can be a lot more verbose. The narrative of a loan request provides the 
reasons why the loan is needed and why the creditors should believe that the borrower is trustworthy enough to pay back the loan and the interest instalments in full. The table also shows that only $0.7 \%$ of applicants who were earlier denied funding had their subsequent listings filled. We should note that the time interval from the first rejection to the second application is, on average, 77 days. The requested loans are mainly used for home refurbishment (41.1\%), personal expenditure (27.2\%) and car purchasing $(15.8 \%){ }^{8}$

An important indicator for lenders is an applicant's credit score. Renrendai.com assigns a credit score to each borrower. The platform's website states that a good record of repayment or regular repayments of a loan contributes to a higher credit score. The higher the credit score, the higher the creditworthiness of a potential borrower. Based on the score, each borrower is classified into one of seven credit categories, from AA to HR (high risk). Panel B of Table 1 shows that the average credit score of all applicants is 14-a credit grade of high risk (HR). The platform also adopts a verification mechanism to check the information submitted by borrowers and their previous borrowing records at Renrendai.com (Tao et al., 2017).

As for borrowers' other characteristics, a Renrendai applicant is, on average, 30 years old. A total of $22.2 \%$ of applicants have a university or higher degree. A total of $38.6 \%$ of borrowers are married and $13.8 \%$ of them are female (Panel B of Table 1). Applicants report an average monthly income of about 3,700 RMB (appr. 530 USD). We observed that $21 \%$ of the applicants have a vehicle. Overall, these descriptive figures are similar to those of other studies that have examined data from Renrendai.com (e.g., Chen et al., 2019; Chen et al., 2018).

We also include two macroeconomic variables and one dummy variable to control for the state of the economy and the level of development of the regions in which the applicants reside, respectively. Macroeconomic variables include the GDP growth rate and the inflation rate. The GDP growth rate refers to the real annual growth rate of the GDP of the province where the borrower resides. Inflation is measured by the logarithmic difference in the consumer price index. To control for geographical differences, we introduce a Tier 1 cities dummy. ${ }^{9}$ The Tier

\footnotetext{
${ }^{8}$ The data also contain information on loan applications for medical expenses. But this segment is very small and corresponds only about $0.5 \%$ of the data amounting to 3,510 entries. We, therefore, merged loans on medical expenses with personal expenditure data.

${ }^{9}$ China's cities are typically divided into four categories based on population size, income level, and institutional environment. Tier 1 cities include Beijing, Shanghai, Guangzhou, Shenzhen, Chengdu, Hangzhou, Chongqing, Wuhan, Suzhou, Xi'an, Tianjin, Nanjing, Zhengzhou, Changsha, Shenyang, Qingdao, Ningbo, Dongguan, and Wuxi.
} 
1 cities dummy captures densely populated and developed metropolitan areas, which provide residents with the best institutional and regulatory framework in the country.

\subsection{To apply or not to apply}

Figure 1 displays the decision tree that the applicants at Renrendai.com have followed in our sample. In particular, the figure provides the number of applications at each Stage $i(i=1, \ldots 4)$, the number of rejected applications (Rejected $\left._{i}, 1, \ldots 4\right)$, the number of filled listings (Approved $_{i}$,

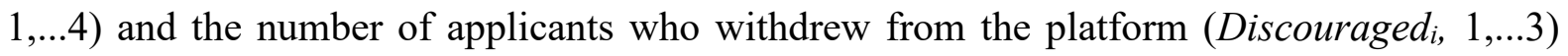
upon failing to raise funds: the discouraged borrower. ${ }^{10}$ Stage 1 displays the total number of first-time applicants, 575,965, considered by lenders. Out of the first time applicants, 421,182 are funded $\left(\right.$ Approved $_{1}$ ) and 154,783 did not get funding (Rejected 1 ). Those who did not get funding, i.e. applicants in Rejected $_{1}$, are then split into two groups; some of them apply again

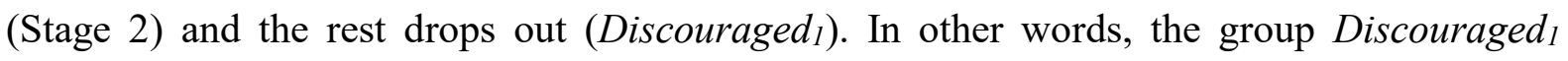
represents (credit constrained) consumers who choose not to apply again after the first rejection. In fact, Figure 1 shows that 27,655 individuals who fail to raise a loan from the previous round apply for funds again (Stage 2), while 127,128 applicants are discouraged

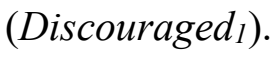

\section{Please insert Figure 1 about here}

When we examine Stage 2 applications, we find that only 804 of the listings are funded (Approved $_{2}$ ) and 26,851 of them are unfilled (Rejected 2 ). At this point, we see that 16,852 of the applicants, whose listings failed in Stage 2, are discouraged, and only 9,999 applicants move to Stage 3. The figure displays all possibilities and provides the outcomes associated with all listings for each group up to 4 unsuccessful loan applications. We stop our scrutiny at Stage 4, as the data become sparse.

\section{Please insert Table 2 about here}

In Table 2, we report the loan and borrower characteristics of discouraged $(\mathrm{D})$, rejected $(\mathrm{R})$ and approved (A) listings, as we follow applicants up to three loan denials. We find that in all attempts, discouraged borrowers, on average, offer similar interest rates for the amount they are willing to borrow to those who apply again. However, those applicants with rejected listings

\footnotetext{
${ }^{10}$ The loss of better-quality applicants upon a rejection can lead to the collapse of the market as at the limit the only borrower type left for funds would be those with a high-risk profile (Akerlof, 1970). However, we do not claim that only the high-quality borrowers drop out of the market. It is also expected that some of the risky borrowers will self-select and leave the market if they think the investors would not lend any funds to them.
} 
offer a slightly higher interest rate for a smaller loan than do the discouraged borrowers. Applicants whose listings are approved have loan terms that are shorter and loan amounts that are significantly smaller than the discouraged borrowers' loan terms and loan sizes, respectively. On average, discouraged borrowers have lower credit scores than do borrowers who reapply or who receive a loan. Also, the word count of approved applicants' loan narratives is generally higher than that of the loan narratives of discouraged and rejected applicants.

When we turn to borrower characteristics, we find that the average discouraged borrower earns less and has a lower education level than the average approved borrower. Moreover, approved borrowers have a longer employment track record than does the average discouraged borrower. Over $50 \%$ of approved borrowers are married, whereas this ratio is much smaller for discouraged and rejected borrowers. Approved borrowers are more likely to own a vehicle than are their discouraged counterparts. Lastly, the proportion of females is about $12-14 \%$ of the total loan applicant population - a figure that is consistent across different stages.

We would like to stress that the average approval rate across all listings is $68 \% .{ }^{11}$ However, when an applicant decides to submit a new funding request after failing to raise funds in an earlier attempt, the probability that the listing will be filled drops quickly in each subsequent stage. For example, in Stage 1, the rate at which a listing is filled is $73 \%$. In Stage 2 , the success rate of an application drops to about 3\%. In the subsequent stage, the approval rate of a loan application for an applicant who has experienced two failed attempts drops further to $2 \%$.

\subsection{Understanding discouraged borrowers' behaviour}

In this section, we investigate the behaviour of discouraged borrowers who failed to attract funding from investors and left the platform. To do so, we employ a logit model to examine the determinants of borrower discouragement. In particular, we explore borrower behaviour when the borrower experiences $\mathrm{n}$ (where $n=1,2,3$ ) consecutive failed funding applications. Our initial regression sample is comprised of those applicants whose first funding application was denied (observed by us). Using this sample, we run the following logit regression for each application node shown in Figure 1:

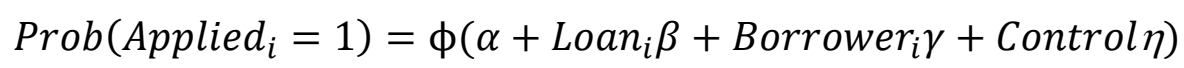

\footnotetext{
${ }^{11}$ This figure includes all applications, including those that were successful from the first attempt.
} 
where $i$ indexes the borrower. ${ }^{12}$ The dependent variable, Applied, equals 1 if the borrower has submitted a loan application and 0 otherwise. $\phi$ denotes the normal distribution function. Loan and Borrower are vectors that capture loan and borrower characteristics, respectively. The vector Loan includes the rate of interest that the borrower is willing to pay, the requested loan amount, the loan term, and the word count of the loan narrative. The vector Borrower contains variables that capture the borrower's personal characteristics including higher education level, university education, income, gender, years of work experience, vehicle ownership, marital status, age, and credit score assigned by the platform.

We estimate model (1) two more times. Next, we restrict our sample to those applicants who had experienced two consecutive failures. In the third attempt, we limit the sample to those who had experienced three consecutive failures. As a result, our models take into account the previous negative experience (or experiences) of each applicant who remains in the sample.

Our empirical approach relates to earlier theoretical work. For instance, Diagne (1999) developed a conceptual framework that explains why financially constrained borrowers are discouraged. In this model, credit-constrained consumers do not apply for new loans because they have very low credit limits or must pay relatively higher interest rates. Renrendai.com, based on the applicant's credit score, also determines the maximum amount that a borrower can raise from the platform. This restriction limits the borrower's choice of loan size regardless of the rate of interest the borrower is willing to offer. The higher the borrower's credit score, the higher the assigned credit limit for which the borrower can apply. In our empirical model, we expect to find that the interest rate and credit score will have a positive effect on borrowers' decision to apply. Hence, consumers with lower credit scores and those who are not willing to pay higher interest rates are likely to be discouraged and to exit the market early.

Income is also an important determinant of borrower behaviour. Borrowers with higher incomes may be less financially needy and have greater confidence that they will not be rejected; therefore, they are more likely to apply for credit (Freel et al., 2012). Likewise, applicants with lower income levels may lack confidence in their self-assessment (Kon and Storey, 2003) because they know that lenders use income as an indicator of a borrower's ability to repay. Consequently, we expect that those with low incomes will be discouraged from applying for a loan after they are rejected on the platform. Furthermore, existing studies have

\footnotetext{
${ }^{12}$ See Chakravarty and Xiang (2013) and Cole and Sokolyk (2016) for a similar modelling strategy.
} 
shown that female borrowers are less likely to apply for debt finance due to a lack of selfconfidence, a perception of supply-side discrimination, and a lower propensity for risk (Treichel and Scott, 2006). If so, females may be discouraged and leave the platform relatively quickly.

Longer work experience with the same employer provides a track record and time for human capital formation. Hence, individuals with longer employment records are expected to succeed in their loan applications and are expected to have a lower likelihood of being discouraged (Mac an Bhaird et al., 2016). Likewise, ownership of an asset, such as a car or real estate, may be useful to reduce asymmetric information problems, as these assets can be taken as collateral. Hence, ownership of an asset is expected to have a positive effect on loan applications. Younger borrowers tend to be overly optimistic. For this reason, coupled with the fact that they are ambitious, they are likely to apply for credit (e.g., Freel et al., 2012). However, with age, an individual acquires experience and human capital. Several studies have documented the fact that willingness to take risks decreases as borrowers age (e.g., Dohmen et al., 2017). To capture nonlinearities, we include a quadratic term in our estimated model and expect an inverted Ushaped pattern between age and the likelihood of reapplying for loans.

In our empirical investigation, we gauge the role that the business cycle plays in determining borrower behaviour by introducing GDP growth rate to the model. We expect that discouragement will be negatively related to the state of the economy, as borrowers tend to be more positive when the economy expands. We also include the inflation rate (the logarithm difference of the Consumer Price Index) to capture the impact that the state of the economic environment has on applications. Research has shown that an increase in inflation is associated with higher uncertainty in the economy (e.g., Caglayan et al., 2008), which could trigger consumer discouragement. We further add a Tier 1 city dummy to control for the geographic location in which the borrower resides. These three variables are contained in vector Control. In the next section, we examine lenders' behaviour when applicants with one or more failed funding requests return to the platform seeking funds to finance their consumption needs. As such, we can understand the interrelations between discouraged and rejected versus approved applicants.

\subsection{Understanding lenders' behaviour}

Do lenders extend loans to persistent applicants? If so, the borrowers should resubmit a new listing after a failed attempt, as eventually each applicant will be successfully funded. However, 
lenders do not necessarily fund all listings. Therefore, it is important to understand which factors affect lenders' funding decisions when the prospective applicant has had one or more earlier failed attempts. To examine the behaviour of lenders, we use a similar empirical model as in the previous section and estimate the following logit model:

$$
\operatorname{Prob}\left(\text { Approved }_{j}=1\right)=\phi\left(\alpha+\operatorname{Loan}_{j} \beta+\text { Borrower }_{j} \gamma+\text { Control } \eta\right)
$$

where $j$ denotes the borrower. The dependent variable, Approved, equals 1 if the loan is filled by the lenders and 0 otherwise. It is well known that banks collect private information about borrowers by tracking the current account transactions of applicants (Han et al., 2009). However, lenders on P2P platforms do not have such amenities. Furthermore, they have limited expertise, economies of scale, or scope in assessing borrowers' creditworthiness (Lin et al., 2013). Iyer et al. (2015) examined the efficiency of screening in peer-to-peer markets and found that individual lenders infer the most from hard financial criteria, as well as non-standard information. Considering the evidence, equation (2) includes listing and borrower characteristics, which lenders can use to overcome information asymmetries in making their lending decisions. Loan-specific characteristics include interest rate, loan amount, term of the loan, and loan description. Borrower characteristics are education, income, gender, employment length, vehicle ownership, marital status, age, and credit score. We estimate equation (2) for three different subsamples for which the applicant has experienced one to three consecutive failed loan listings.

The model is expected to capture the fact that lenders will fund those applicants with low risk so as to maximize the likelihood that the loan will be paid in full. Higher interest rates indicate an increase in the riskiness of the borrower. Hence, the coefficient associated with interest rate is expected to take a negative sign. Similarly, we expect that applicants with better credit ratings will be funded, as such borrowers are considered to be low-risk. A larger loan amount could be taken as an indicator of increasing financial needs, which may lead to liquidity problems and a higher level of uncertainty (Brancati, 2015). We expect that borrowers with a greater need for funds will have more difficulty accessing the required amount. Moreover, the narrative for the loan is likely to play a significant role. However, it is also likely that the lender may overlook the narrative if the final lending decision is based on hard information.

Borrowers with less education may have lower financial literacy. Potential lenders could use education as an indicator of borrowers' capacity to repay the loan, making it costlier for lesseducated applicants to borrow (Lusardi and Mitchelli, 2007). Therefore, a funding application 
from a less-educated borrower is more likely to be rejected. Likewise, borrowers with lower income are more likely to be rejected for credit. On a similar note, Colombo and Grilli (2007) provided support for the claim that prior employment experience should play a positive role in debt financing, as this would constitute a track record for the borrower. Hence, we expect that the longer the work experience a potential borrower has, the higher the probability that the application will be funded. Age is also expected to be a factor, as it can be associated with more experience. The quadratic term is added to the model to account for potential non-linearities. ${ }^{13}$ Car ownership can be associated with being creditworthy, as cars can be taken as collateral. Consequently, such applicants are more likely to be funded. To examine the reaction of P2P lenders to the gender of an applicant, we include the dummy Female (which equals 1 if an applicant is female and 0 otherwise) in our model. Indeed, academic and policy circles are widely discussing gender-based credit discrimination in raising bank loans (e.g., Pham and Talavera, 2018). If lenders on Renrendai.com discriminate against applicants on the basis of gender, this dummy should take a significant sign.

The vector Control embodies both GDP growth and the inflation rate, allowing us to control for the business cycle and the stability of the economic environment. ${ }^{14} \mathrm{We}$ expect that the GDP growth rate will have a positive effect and that inflation will have a negative effect on lenders' decisions. In our models, we also control for the time interval (in days) between the initial loan rejection and the next funding application. Last but not least, a Tier 1 city dummy is included to control for the geographic location of the borrower.

\section{Empirical analysis}

In what follows, we first examine the behaviour of discouraged borrowers. We then evaluate the factors that the lenders value when they supply credit to online funding applications. In doing so, we aim to shed light on what leads to borrower discouragement in P2P online credit markets.

\footnotetext{
13 An inverse-U-shape relationship is found between age and investment skills (Agarwal et al., 2009; Korniotis and Kumar, 2011), loan approval (Muravyev et al., 2009), and even entrepreneurial job satisfaction (Pham et al., 2018).

${ }^{14}$ We have also experimented with a number of additional control variables, including a vector of dummy variables corresponding to purpose of loan (car purchase, education, home refurbishment, housing or wedding). The obtained results are quantitatively similar and available upon request.
} 


\subsection{Examining the discouraged borrowers}

Table 3 presents the marginal effects of loan and borrower characteristics as modelled in equation (1): applicants decide to re-apply for a loan or not after experiencing $n$ (where $n=1$, 2, 3) earlier rejections. ${ }^{15}$ The table shows that applicants who submit a new funding request after experiencing an earlier rejection are prepared to pay higher interest rates than they were in the previous round of financing. This suggests that the presence of applicants who are willing to offer higher interest rates to lenders will discourage some of the qualified candidates from applying again after a failed attempt. In fact, this observation is consistent with Brown et al. (2011), who have shown that high interest rates represent the most significant factor affecting creditworthy borrowers' decision not to apply for loans.

\section{Please insert table 3 about here}

Loan amount takes a positive sign, indicating that those who reapply for funds after a rejection are those who need higher amounts for their planned consumption. ${ }^{16}$ Note that this effect is significant in columns 2 and 3 . When we consider the term and the loan amount, discouraged borrowers appear to need smaller amounts of funds for a shorter term. Perhaps when an applicant feels that investors will not approve small short-term loans, she will be discouraged about returning to the platform again but will turn to other sources of funds, despite the high costs. ${ }^{17}$ The last listing attribute we examine is the role of the word count of the loan description. We find that word count has a negative and significant effect for the first two rounds: A borrower who reapplies presents her case more concisely. This may be reasonable, as short and sharp loan narratives can reduce the asymmetric information between the lenderborrower space (Han et al., 2009). However, parsimony in presenting a case may not necessarily serve the borrower well. In fact, when we examine the lenders' decisions, we see that lenders do not pay attention to soft information such as loan narratives. Overall, the discouraged applicant is someone who does not want to pay a high interest rate, who seeks less credit for a shorter term, and who perhaps provides a more detailed loan narrative.

\footnotetext{
15 Clustering errors by loan purposes or by listings yield similar p-values. Detailed results are available upon request from the authors.

${ }^{16}$ Focusing on firm-level data, Tang et al. (2017) reported that the amount of the loan does not affect the probability that the business manager is a discouraged borrower.

${ }^{17}$ Interest rates charged by loan sharks or payday lenders in China are much higher than those that P2P lenders receive. Yet, unlike funds from other sources, such funds are available to anyone who agrees to pay the rates.
} 
Having scrutinized the role of listing characteristics on being discouraged, we now examine the extent to which borrower characteristics affect the decision to reapply. We should first stress that those who reapply have better credit scores. The coefficient associated with credit score is positive and statistically significant at the $1 \%$ level in all cases. In fact, basic statistics provided in Table 1 on the raw data have already shown that (on average) the discouraged borrower has a lower credit score assigned by the platform as compared to those who are approved or who reapplied. Cole and Sokolyk (2016) argued that discouraged borrowers do not apply because they expect to be rejected by lenders who use credit scores as a screening device. To that end, the platform website states that the credit score will be higher when the borrower has a track record of successful repayment of loans. ${ }^{18}$ This policy fails the discouraged and rejected borrowers, as neither type has a track record with the platform. This is a major drawback for credit-constrained borrowers who require external funds for their needs.

When we examine the role that education plays in being discouraged, we find that education takes a negative coefficient in all columns. The coefficient estimate is significant at the $5 \%$ level for the first column and at the $10 \%$ level in the second column. The significance of education disappears in the last column. ${ }^{19}$ These results are meaningful and expected. Overall, education can be taken as a signal of future income, as one can argue that better-educated individuals will enjoy higher levels of income in the future. Furthermore, better-educated applicants, who are financially literate, would not be willing to pay high interest rates to enjoy current consumption. We also see that income level is significant only in column two and has a negative effect. Like educated applicants, those with better income levels are expected to achieve even higher levels of income in the future and would not necessarily want to pay high interest rates to increase their current consumption. Hence, it is reasonable that applicants with better education and higher income are discouraged early.

An interesting finding is that female borrowers are more likely to leave the market early as compared to male borrowers. Marginal analysis shows that there is a 3.6-percentage-points greater probability of female borrowers being discouraged from reapplying for loans after the

\footnotetext{
${ }^{18} \mathrm{See}$ https://www.renrendai.com/help/borrow/borrow!creditrating.action, accessed on 21 February 2019.

${ }^{19}$ When we move through the application stages, the number of reapplicants drops to $27 \mathrm{~K}$ and $10 \mathrm{~K}$. Considering that better educated applicants have already dropped out in earlier stages, significance throughout the exercise should decline as we move across the columns.
} 
first rejected funding application. The probability reduces to 2.7 percentage points following the second rejected application. This finding is similar to those of Storey (2004) and Chakravarty and Xiang (2013), who provided evidence that female business owners are more likely to be discouraged. When we turn to the remaining borrower characteristics, including work experience (employment length), vehicle ownership, or marital status, we do not find a consistent and significant impact. Age, by contrast, has a significant and positive effect. However, we also find that age squared takes a negative coefficient, suggesting that there is an inverted U-shape relation between age and reapplication. The likelihood of application reduces with age due to increased risk aversion (e.g., Dohmen et al., 2017).

Variables that control the state of the economy do not present a stable relation, yet their inclusion (or exclusion) does not affect our conclusions about our main variables. By contrast, we find that applicants from Tier 1 cities are discouraged earlier - an effect that is significant for all rounds. This may be due to the availability of funding channels for people living in large cities, including different channels of shadow banking, informal loans, or even payday loans.

Overall, our investigation shows that individuals with certain characteristics will be discouraged from re-applying for a loan more easily than others will. In fact, Crook (1999: 166) argued that the characteristics that affect the probability of discouragement "are those which a household may believe are used by lenders to decide on a credit granting decision". Most notably, data provide evidence that female applicants are discouraged early. Yet, female discouragement is worrisome and, possibly, a result of a lack of self-confidence, a perception of supply-side discrimination, and a lower propensity for risk (Treichel and Scott, 2006).

\subsection{Lender reaction towards financing borrowers with failed attempts}

Having investigated the reasons why an applicant may be discouraged from submitting a new loan request after one or more failed attempts, we next explore the reaction of lenders towards financing borrowers who apply after experiencing loan rejections. Table 4 displays the marginal effects estimated for equation (2).

\section{Please insert table 4 about here}

Examining loan characteristics, we find that the interest rate and the loan amount both consistently take a negative coefficient for all rounds of applications. We also find that lenders favour longer-term loans (significant in column 1 at the $1 \%$ level). This suggests that lenders are not interested in extracting higher interest payments from reapplicants but that they prefer to finance low-risk borrowers who will make regular payments for a longer term. Lenders also 
favour listings that request less, perhaps to ensure full payment of the capital and the interest. Furthermore, by favouring smaller loans, investors can invest across several listings to construct a diversified loan portfolio. The results indicate that the loan narrative does not have any significant impact on lenders' decisions. This suggests that lenders, in their lending decision, are more influenced by hard evidence than by soft information. Time intervals between loan applications have a consistently positive effect on loan approval. A shorter time interval between consecutive loan applications indicates a higher level of financial distress on the part of borrowers. Financial distress increases the likelihood of borrower default (e.g., Lee and Mullineaux, 2004), which, in turn, negatively impacts lenders' funding decisions.

When we turn to examine borrower characteristics, we observe that credit score is of paramount importance. Lenders finance applicants who have high credit scores. In that sense, those who have raised funds in the past and who have not missed a payment will be at an advantage because Renrendai.com assigns a higher credit rating to these borrowers. By contrast, the platform gives low credit ratings to first-time applicants, who get hardly any funding unless lenders have additional information about such applicants. In this context, it is rational for borrowers with low credit ratings to be discouraged early after a failed attempt. Education, income, and employment have a positive effect on lenders' decision-making progress. Yet, lenders pay more attention to income as its effect is always significant whereas education is significant only in the first stage while employment is significant in the second stage. Interestingly, vehicle ownership plays a negative role; lenders may not be keen on vehicle ownership, for they may see a vehicle as more of a liability than an asset. In inspecting the table, we see that the coefficient of dummy Female does not take a significant coefficient in any of the columns. This shows that lenders do not discriminate applicants on the basis of gender.

Among control variables, our results reveal that macroeconomic environment does not play a significant role in affecting lenders' decision problem. Furthermore, there is strong evidence that applicants' geographical location does not matter to the lending problem. Hence, creditworthy applicants from larger cities should be encouraged to apply after they experience a failed round; they should not turn to other sources of finance that require high interest rates such as payday loans.

It is clear from our investigation that although P2P platforms may allow a wider group of consumers to access credit, a credit-constrained consumer who does not have the appropriate credit score will not be able to raise funds, even from a P2P platform. Yet, from the point of 
view of lenders, credit rating is important, as there is little else to depend upon to resolve asymmetric information problems. We show that education, income, and employment length have a positive effect on lenders' decision to fund; lenders fund financially literate borrowers. Most importantly, we find that gender does not play a significant role in lenders' decisionmaking process. This result is important, as we differ from the evidence presented by earlier empirical studies, which suggested that institutional lenders are prone to stereotyping consumers in their lending decisions (e.g., Blanchflower et al., 2003).

\subsection{Are borrowers punished for previous rejections?}

This section provides additional evidence about how lenders assess borrowers' previous experience if they had a mixture of successful and failed applications. In this case, our sample differs from that which we examined in the previous subsection and is restricted to borrowers with at least four loan applications (including both rejections and approvals). ${ }^{20}$ Two additional variables are added to equation (2): the cumulative number of previous rejections and the cumulative success rate, measured as the number of approved applications divided by the total number of applications. The results presented in Table 5 are generally consistent with our earlier findings. The table shows that borrowers who are willing to pay higher interest rates are less likely to be funded. Lenders tend to fund listings that request a smaller amount for a shorter term. The term of the loan is shorter perhaps due to the presence of an earlier loan received from the platform, as lenders must be keen about full payment of the loan. Different from Table 4, here we see that the coefficient of dummy Female is consistently positive yet economically insignificant. We interpret this observation through the fact that female applicants who return to the platform are stronger than other applicants. Similarly, we find a strong negative effect of vehicle ownership on borrowers' decision to lend. As noted earlier, this may be driven by lenders' belief that a vehicle is a liability rather than an asset. This is reasonable, as applicants are credit-constrained and vehicle ownership implies a constant drain of funds due to maintenance and running costs.

We also find that both credit score and borrowers' income have a positive effect on lenders' decision to fund an application. However, the word count of the loan narrative is significant and has a positive effect. It seems that soft information plays a significant role when a borrower

\footnotetext{
${ }^{20}$ We conducted a similar investigation in which we restricted our attention to at least five loan applications with one or more successful outcomes. The results were similar and are available from the authors upon request.
} 
has had several earlier loan applications. Regression results also show that the knowledge that an applicant had a successful or an unsuccessful earlier attempt on the platform is valuable for lenders. ${ }^{21}$ The table shows that unsuccessful applications have a negative effect while successful attempts have a positive effect on lenders' granting a loan to an applicant. This finding is meaningful because it suggests that earlier success or failure on the platform provides a signal to lenders about the quality of applicants returning to the platform. Lenders utilize this signal in their lending problem and allocate funds accordingly.

Please insert table 5 about here

\subsection{Extensions}

We have provided evidence that female borrowers tease themselves out of the market after a failed attempt earlier than do their male counterparts. This could be due to differences in borrower and listing characteristics between female and male applicants. We examine this possibility by 1:1 matching male and female applicants by borrower and loan term characteristics and estimating average treatment effect on the treated (ATT). ${ }^{22}$ This approach is also repeated for modelling lenders decisions. Panel A of Table 6 displays the results for borrowers' decision problem and it shows that dummy Female has a negative and highly significant coefficient in columns (1) and (2), supporting our earlier findings. The probability of female borrowers re-applying for funds will be $3.5 \%$ and $2.2 \%$ less than that of their male counterparties after a single failed attempt and after two failed attempts, respectively. Panel B of Table 6 reports the average treatment when we consider lenders' decision to approve (or not approve) a loan and shows that dummy Female takes a significant and positive coefficient only in columns (2) and (3). Considering the coefficient size as well as the number of applicants that move into second and third stages the significance of coefficients does not suggest any economic importance. The results obtained here are consistent with our earlier finding that female applicants withdraw themselves from the market early and that investors do not discriminate against applicants on the basis of gender (e.g., Talavera et al., 2012).

Please insert table 6 about here

\footnotetext{
${ }^{21}$ Renrendai.com allows borrowers to create new loan applications before an existing loan is paid off.

22 Detailed discussions about the propensity score matching approach can be found in Rosenbaum and Rubin (1983), Rosenbaum (2001) and Chen et al (2017). We have also tried nearest neighbour matching and received quantitatively similar results, available upon request.
} 
We have also undertaken additional analyses to check the validity of our results. We control for the types of loans that applicants seek by including a vector of dummy variables corresponding to purpose of loan, including car purchase, education, home refurbishment, housing or wedding. The effects of explanatory variables and Pseudo R-square are similar to those results reported in the earlier tables. The results on the loan purpose variables are reported in Table $7 .^{23}$ Borrowers requesting loans for the purposes of car purchasing, home refurbishment and wedding have a higher likelihood to apply after a failed loan request.

Please insert table 7 about here

\section{Conclusion}

To the best of our knowledge, we have made the first attempt to develop an understanding of discouraged borrowers in P2P lending markets. Particularly, we investigate the extent to which listing- and borrower-specific characteristics affect borrower discouragement when an applicant experiences one or more failed attempts to raise funds in an emerging economy on a P2P platform. As we examine borrower behaviour, we also pay attention to lender behaviour to understand the dynamics of discouragement between the demand and supply sides of the funding problem. To carry out the analysis, we track applicants who posted multiple funding listings on Renrendai.com, one of the largest online platforms in China, between October 2010 and October 2018.

We find that discouraged borrowers are different from rejected or approved borrowers in terms of their personal, financial, and loan characteristics. The data provides evidence that discouraged borrowers have more education and a reasonable income level, both of which attract a lender's attention. Yet, they also have low credit ratings, perhaps due to the fact that they have no earlier funding experience through the platform. Thus, we argue that (some of the) discouraged borrowers are financially literate and prefer to wait rather than to pay high interest rates to adjust for their consumption timing. When we examine lender (investor) behaviour, we show that investors care about hard information rather than soft information. Investors fund borrowers who are low-risk, as captured by high credit scores. Furthermore, investors do not seek applicants who are willing to pay high interest rates but do fund low-risk borrowers who will make regular payments over a longer term. Most importantly, unlike

\footnotetext{
${ }^{23}$ The results on remaining variables are quantitatively similar as shown in Tables 3 . The full table is available from the authors upon request.
} 
several other studies, we provide evidence that P2P investors in China do not make their funding decisions based on the gender of the applicant. That is, female applicants do not face gender discrimination. Another interesting finding is that although applicants from larger cities are quickly discouraged, lenders do not have a tendency to screen out applicants based on regional preferences. There is clear evidence that lenders are concerned about lending to borrowers who will pay the interest instalments and the principal on time.

Overall, we show that borrower discouragement is a significant phenomenon on a prominent P2P lending platform in China and argue that regulatory bodies and P2P lending platforms should develop the means (training and online assistance) by which to explain the process and provide information to borrowers about the aspects that matter to lenders. This finding is particularly useful for decision-makers in both developed and developing countries. Our results also show that while the fintech industry can improve access to financial resources for the most credit-constrained, the resolution of asymmetric information problems will be the main challenge. To overcome this problem, regulators and platform owners should strive to improve information transparency in relation to the construction of credit scores and the rules of operation of P2P lending platforms. This could even be facilitated by the establishment of a country-level credit score institution that could assess the risk of each potential borrower.

While our analysis provides very interesting insights, there are several limitations, caused primarily by data availability. First, we do not observe borrowers' applications to other financing channels - and to other crowdlending platforms in particular. Second, the sociodemographic characteristics of investors might also be important in affecting the decisionmaking process. These directions are left for future studies. 


\section{References}

Agarwal, S., Driscoll, J., Gabaix, X., \& Laibson, D. 2009. The Age of Reason: Financial Decisions over the Life Cycle and Implications for Regulation. Brookings Papers on Economic Activity, 2009, 51-101.

Allen, F., Demirguc-Kunt, A., Klapper, L. and Martinez Peria, M. 2016. The foundations of financial inclusion: Understanding ownership and use of formal accounts, Journal of Financial Intermediation, 27(C), 1-30.

Akerlof, G. A. 1970. The market for 'Lemons': Quality uncertainty and the market mechanism. Quarterly Journal of Economics, 84(3), 488-500.

Attanasio, O. P., Goldberg, P., and Kyriazidou, E. 2008. Credit constraints in the market for consumer durables: Evidence from micro data on car loans. International Economic Review, 49(2), 401-436

Bergstresser, D. 2010. Banking market concentration and consumer credit constraints: Evidence from the 1983 Survey of Consumer Finances. Harvard Business School working paper 10-077.

Blanchflower, D. G., Levine, P. B. and Zimmerman, D. J. 2003. Discrimination in the small business credit market, The Review of Economics and Statistics, 85(4), 930-43.

Brancati, E., 2015. Innovation financing and the role of relationship lending for SMEs. Small Business Economics, 44(2), 449-473.

Brown, M., Ongena, S., Popov, A., and Yeşin, P. 2011. Who needs credit and who gets credit in Eastern Europe? Economic Policy, 26(65), 93-130.

Bruhn, M., and Love, I. 2014. The real impact of improved access to finance: Evidence from Mexico. Journal of Finance, 69(3), 1347-76.

Caglayan, M., Filiztekin A., and Rauh M.T., 2008. Inflation, price dispersion, and market structure, 2008. European Economic Review, 52(7), 1187-1208.

Caglayan, M., Talavera, O. and Zhang, W., 2019. Herding behaviour in P2P lending markets. BOFIT Discussion Paper 22/2019.

Chakravarty, S., and Xiang, M., 2013. The international evidence on discouraged small businesses. Journal of Empirical Finance, 20(1), 63-82.

Chen, X., Huang, B., \& Ye, D. 2019. Gender gap in peer-to-peer lending: Evidence from China. Journal of Banking \& Finance, forthcoming.

Chen, J., Jiang, J., \& Liu, Y. J. 2018. Financial literacy and gender difference in loan performance. Journal of Empirical Finance, 48, 307-320.

Chen, J., Leung, W.S. \& Goergen, M. 2017. The impact of board gender composition on dividend payouts. Journal of Corporate Finance, 43, 86-105

Cole, R., and Sokolyk, T. 2016. Who needs credit and who gets credit? Evidence from the surveys of small business finances. Journal of Financial Stability, 24, 40-60.

Colombo, M. G., and Grilli, L. 2007. Funding gaps? Access to bank loans by high-tech startups. Small Business Economics, 291(2), 25-46.

Crook, J. 1999. Who is discouraged from applying for credit? Economics Letters, 65(2), 165172. 
De Roure, C., Pelizzon, L., and Tasca, P. 2016. How does P2P lending fit into the consumer credit market? Discussion Paper Deutsche Bundesbank No 30/2016.

Diagne, A. 1999. Determinants of household access to and participation in formal and informal credit markets in Malawi. FCND Discussion Paper 67

Dohmen, T., Falk, A., Golsteyn, B., Huffman D., and Sunde U. 2017. Risk attitudes across the life course, Economic Journal, 127(605), F95-F116.

Dupas, P., and Robinson J. 2013. Savings Constraints and Microenterprise Development: Evidence from a field experiment in Kenya. American Economic Journal: Applied Economics, 5(1), 163-92.

Ferrando, A., \& Mulier, K. (2015). The real effects of credit constraints: evidence from discouraged borrowers in the euro area. Working Paper Series 1842, European Central Bank.

Freel, M., Carter, S., Tagg, S., and Mason, C. 2012. The latent demand for bank debt: Characterizing “discouraged borrowers". Small Business Economics, 38(4), 399-418.

Gao, G., Caglayan, M., Li, Y., and Talavera, O., 2020. Expert Imitation in P2P Markets. Department of Economics Working Paper 20-10, University of Birmingham.

Han, L., Fraser, S., and Storey, D. J. 2009. Are good or bad borrowers discouraged from applying for loans? Evidence from US small business credit markets. Journal of Banking and Finance, 33(2), 415-424.

Hawley, C. B. and Fujii, E. T. 1990. Discouraged applicants for consumer credit: Empirical evidence and implications for public policy. Economics Letters, 33(1), 83-86.

Herzenstein, M., Andrews, R. L., Dholakia, U. M., and Lyandres, E. 2008. The democratization of personal consumer loans? Determinants of success in online peer-to-peer lending communities. Boston University School of Management Research Paper 146.

Iyer, R., Khwaja, A. I., Luttmer, E. F., and Shue, K. 2015. Screening peers softly: Inferring the quality of small borrowers. Management Science, 62(6), 1554-1577.

Japelli, T. 1990. Who is credit constrained in the U.S. economy? Quarterly Journal of Economics, 105(1), 219-234

Johnson, K. W., and Li, G. 2010. The Debt-Payment-to-Income Ratio as an Indicator of Borrowing Constraints: Evidence from Two Household Surveys. Journal of Money, Credit and Banking, 42(7), 1373-1390.

Kempson E, Atkinson A, Pilley O. 2004. Policy level response to financial exclusion in developed economies: lessons for developing countries. Report of Personal Finance Research Centre, University of Bristol.

Kim, H. and Moor, L. 2017, The case of crowdfunding in financial inclusion: A survey. Strategic Change, 26(2), 193-212.

Kon, Y., and Storey, D. J. 2003. A theory of discouraged borrowers. Small Business Economics, 21(1), 37-49.

Korniotis, G. M., \& Kumar, A. 2011. Do older investors make better investment decisions? The Review of Economics and Statistics, 93(1), 244-265.

Lee, S. W., \& Mullineaux, D. J. 2004. Monitoring, financial distress, and the structure of commercial lending syndicates. Financial Management, 107-130. 
Lin, M., Prabhala, N. R., and Viswanathan, S. 2013. Judging borrowers by the company they keep: Friendship networks and information asymmetry in online peer-to-peer lending. Management Science, 59(1), 17-35.

Lusardi, A. and Mitchelli, O. S. 2007. Financial literacy and retirement preparedness: Evidence and implications for financial education. Business Economics, 42(1), 35-44.

Lyons, A. C. 2003. How credit access has changed over time for US households. Journal of Consumer Affairs, 37(2), 231-255.

Mac an Bhaird, C., Vidal, J. S., and Lucey, B. 2016. Discouraged borrowers: Evidence for Eurozone SMEs. Journal of International Financial Markets, Institutions and Money, 44, 4655.

Muravyev, A., Talavera, O., \& Schäfer, D. (2009). Entrepreneurs' gender and financial constraints: Evidence from international data. Journal of Comparative Economics, 37(2), 270286.

Pham, T. and Talavera, O., 2018. Discrimination, social capital, and financial constraints: The case of Viet Nam. World Development, 102, 228-242.

Pham, T., Talavera, O. and Zhang, M., 2018. Self-employment, financial development, and well-being: Evidence from China, Russia, and Ukraine. Journal of Comparative Economics, 46(3), 754-769.

Rosenbaum, Paul. 2001. Observational Studies: Overview.

Rosenbaum, P.R. and Rubin, D.B., 1983. The central role of the propensity score in observational studies for causal effects. Biometrika, 70(1), 41-55.

Rostamkalaei, A., Nitani, M., \& Riding, A. 2018. Borrower discouragement: the role of informal turndowns. Small Business Economics, 1-16.

Sarma, M. and Pais, J. 2011, Financial inclusion and development. Journal of International Development, 23(5): 613-628.

Storey, D. J. 2004. Racial and gender discrimination in the micro firms credit market?: Evidence from Trinidad and Tobago. Small Business Economics, 23(5), 401-422.

Talavera, O., Xiong, L. and Xiong, X., 2012. Social capital and access to bank financing: The case of Chinese entrepreneurs. Emerging Markets Finance and Trade, 48(1), 55-69.

Tang, Y., Deng, C., and Moro, A. 2017. Firm-bank trusting relationship and discouraged borrowers. Review of Managerial Science, 11(3), 519-541.

Tao, Q., Dong, Y., and Lin, Z. 2017. Who can get money? Evidence from the Chinese peer-topeer lending platform. Information Systems Frontiers, 19(3), 425-441.

Treichel, M. Z., and Scott, J. A. 2006. Women-owned businesses and access to bank credit: Evidence from three surveys since 1987. Venture Capital, 8(1), 51-67. 
Figure 1. Dichotomy of decision making by consumption loan borrowers and lenders

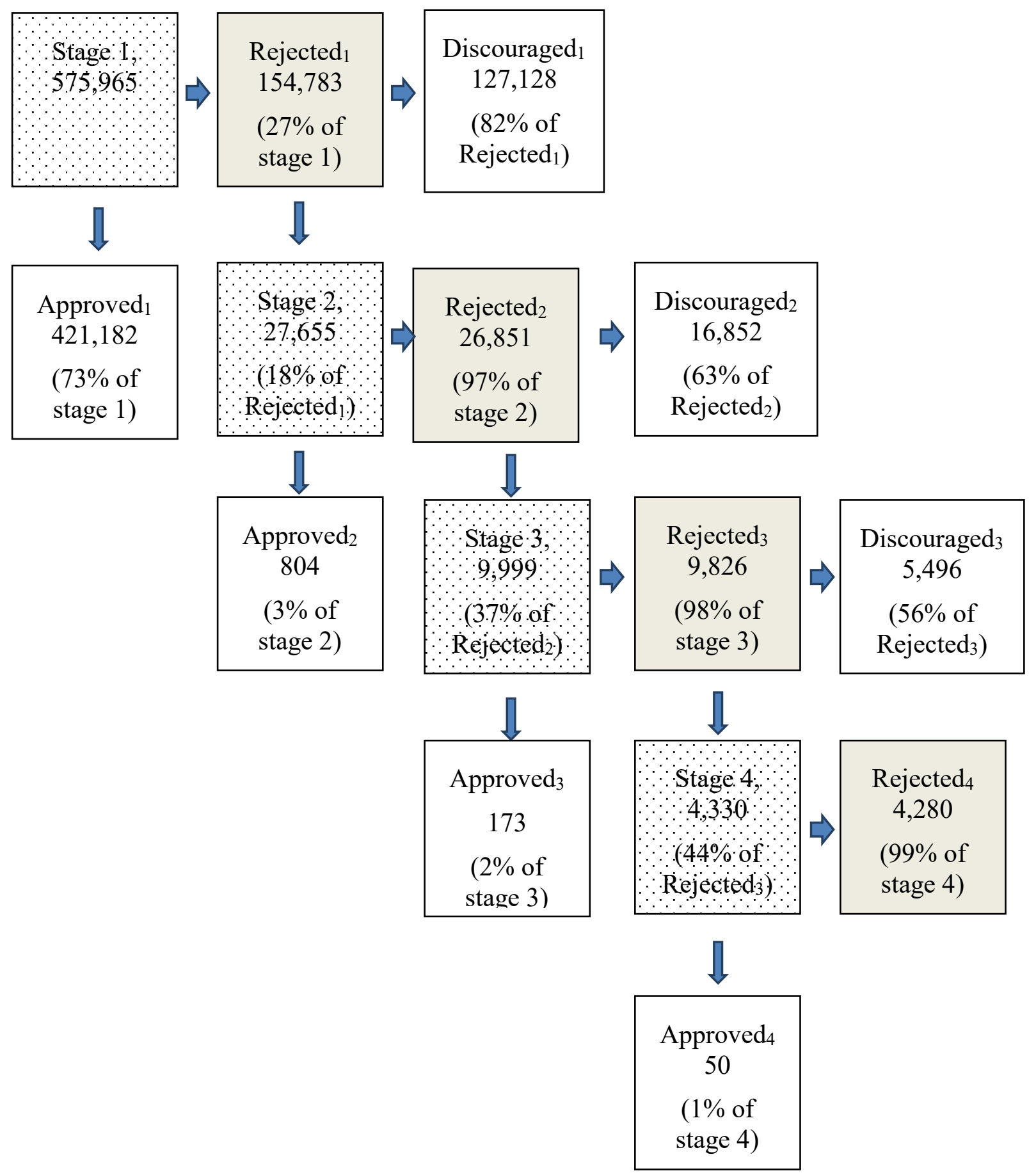

Note. This decision tree shows the number of loan requests (dotted box) along with rejected (shaded box) and funded (Approved) applications. Those who dropped out of the market (Discouraged) are also shown. The number of observations and the associated percentages in each level are reported. 
Table 1. Descriptive statistics

\begin{tabular}{lrrrrc}
\hline Variable & Mean & \multicolumn{1}{c}{ SD } & Median & P25 & P75 \\
\hline Panel A: Listing details & & & & & \\
\hline Loan Amnt & 52.014 & 68.819 & 40 & 12 & 50 \\
Int. Rate & 13.470 & 2.681 & 13 & 12 & 13 \\
Term & 18.408 & 8.992 & 24 & 12 & 24 \\
Word count & 46.698 & 36.211 & 34 & 25 & 56 \\
Funded & 0.007 & 0.084 & 0 & 0 & 0 \\
Time interval & 77.092 & 161.066 & 20 & 5 & 74 \\
\hline Loan purpose: car purchase & 0.158 & 0.365 & 0 & 0 & 0 \\
Loan purpose: education & 0.029 & 0.169 & 0 & 0 & 0 \\
Loan purpose: home refurbishment & 0.411 & 0.492 & 0 & 0 & 1 \\
Loan purpose: housing & 0.081 & 0.272 & 0 & 0 & 0 \\
Loan purpose: personal expenditure & 0.272 & 0.445 & 0 & 0 & 1 \\
Loan purpose: wedding & 0.049 & 0.216 & 0 & 0 & 0 \\
\hline Panel B: Borrower characteristics & & & & & \\
\hline Age & 29.627 & 6.309 & 28 & 25 & 32 \\
Education & 0.222 & 0.415 & 0 & 0 & 0 \\
EmpLength & 1.365 & 1.000 & 1 & 1 & 2 \\
Female & 0.138 & 0.345 & 0 & 0 & 0 \\
Income & 3.701 & 0.955 & 4 & 3 & 4 \\
Marriage status & 0.386 & 0.487 & 0 & 0 & 1 \\
Vehicle & 0.210 & 0.407 & 0 & 0 & 0 \\
Credit score & 14.396 & 19.700 & 20 & 0 & 20 \\
Applied & 0.179 & 0.383 & 0 & 0 & 0 \\
\hline Panel C: Macroeconomic factors & & & & & \\
\hline GDP growth & & 0.743 & 2.300 & 1.900 & 2.500 \\
\hline & 0.412 & 0 & 0 & 0 \\
\hline
\end{tabular}

Note: Number of observations: 202,409. Loan Amnt is the amount of loan requested by the borrower in thousand RMB. Int. Rate is the rate of interest in percentages (\%) that borrower is willing to pay. Term is loan maturity in months. Word count is the word count of loan narrative posted by the borrower. Funded is a dummy variable, equal to 1 if the listing is funded; 0 otherwise. Time interval is the time (in days) between the initial loan rejection and the borrower's next funding application. The purpose of a funding request includes: Car purchase (=1 if loan is requested for car purchasing; 0 otherwise), Education (=1 if loan is requested for education; 0 otherwise), Home refurbishment ( $=1$ if loan is requested for the use of home refurbishment; 0 otherwise), Housing (=1 if loan is requested for housing; 0 otherwise), Personal expenditure ( $=1$ if loan is requested for personal expenditure; 0 otherwise) and Wedding (=1 if loan is requested for wedding expenses; 0 otherwise). Age is the age of borrower 
in years. Education equals to 1 if the borrower has at least a university degree. EmpLength is work experience in number of years. Female equals to 1 if the borrower is female; 0 otherwise. Income is the monthly income of the borrower in thousand RMB. Marriage status equals to 1 if the borrower is married; 0 otherwise. Vehicle equals to 1 if the borrower has a car; 0 otherwise. Credit score is the credit score of the borrower (as of when the listing was created). Applied equals to 1 if the borrower summited a loan application after first rejection; 0 otherwise. $G D P$ growth is annual growth rate of real provincial GDP where the borrower is resident. Inflation is measured by consumer price index. Tier lcities equals to 1 if the borrower is living in a Tier 1 city; 0 otherwise. 
Table 2. Summary statistics by number of rejected consecutive attempts

\begin{tabular}{lccccccccc}
\hline & \multicolumn{1}{c}{ Failed first attempt } & \multicolumn{3}{c}{$\begin{array}{c}\text { Failed first two } \\
\text { attempts }\end{array}$} & \multicolumn{3}{c}{$\begin{array}{c}\text { Failed first three } \\
\text { attempts }\end{array}$} \\
& $\mathrm{D}$ & $\mathrm{R}$ & $\mathrm{A}$ & $\mathrm{D}$ & $\mathrm{R}$ & $\mathrm{A}$ & $\mathrm{D}$ & $\mathrm{R}$ & $\mathrm{A}$ \\
\hline & $(1)$ & $(2)$ & $(3)$ & $(4)$ & $(5)$ & $(6)$ & $(7)$ & $(8)$ & $(9)$ \\
\hline Loan Amnt & 53.13 & 49.70 & 15.34 & 50.55 & 48.33 & 13.78 & 47.97 & 47.02 & 13.50 \\
Int. Rate & 13.33 & 13.67 & 13.01 & 13.57 & 13.70 & 13.09 & 13.53 & 13.72 & 13.26 \\
Term & 17.93 & 19.02 & 13.43 & 18.78 & 19.55 & 12.88 & 19.18 & 19.79 & 14.10 \\
(months) & & & & & & & & & \\
Word count & 45.97 & 47.66 & 58.40 & 47.14 & 46.97 & 55.23 & 46.60 & 46.22 & 46.02 \\
Credit score & 8.64 & 22.64 & 101.30 & 18.03 & 24.07 & 98.64 & 21.45 & 24.40 & 95.48 \\
\hline Age & 29.57 & 29.74 & 31.23 & 29.70 & 29.81 & 30.09 & 29.84 & 29.88 & 30.92 \\
Education & 0.21 & 0.23 & 0.42 & 0.23 & 0.23 & 0.38 & 0.23 & 0.23 & 0.38 \\
EmpLength & 1.33 & 1.39 & 1.79 & 1.36 & 1.40 & 1.80 & 1.38 & 1.40 & 1.66 \\
Female & 0.14 & 0.13 & 0.14 & 0.13 & 0.12 & 0.14 & 0.13 & 0.12 & 0.14 \\
Income & 3.68 & 3.73 & 3.81 & 3.73 & 3.73 & 3.73 & 3.72 & 3.73 & 3.66 \\
Marriage & 0.34 & 0.46 & 0.59 & 0.45 & 0.48 & 0.55 & 0.48 & 0.48 & 0.60 \\
status & & & & & & & & & \\
Vehicle & 0.17 & 0.26 & 0.29 & 0.25 & 0.27 & 0.27 & 0.26 & 0.27 & 0.24 \\
\hline N & 127,128 & 27,655 & 804 & 16,852 & 9,999 & 173 & 5,496 & 4,330 & 50 \\
\hline
\end{tabular}

Note: This table reports loan and borrower characteristics of discouraged (D), rejected (R) and approved (A) listings, by the number of earlier failed attempt(s). Loan Amnt is the amount of loan requested by the borrower in thousand RMB. Int. Rate is the rate of interest in percentages (\%) that borrower is willing to pay. Term is loan maturity in months. Word count is the word count of loan narrative posted by the borrower. Age is the age of borrower in years. Education equals to 1 if the borrower has at least a university degree. EmpLength is work experience in number of years. Female equals to 1 if the borrower is female; 0 otherwise. Income is the monthly income of the borrower in thousand RMB. Marriage status equals to 1 if the borrower is married; 0 otherwise. Vehicle equals to 1 if the borrower has a car; 0 otherwise. Credit score is the credit score of the borrower (as of when the listing was created). 
Table 3. Borrower's decision to apply for a loan or not

\begin{tabular}{|c|c|c|c|}
\hline & $\begin{array}{l}\text { Failed first } \\
\text { attempt (1) }\end{array}$ & $\begin{array}{l}\text { Failed first two } \\
\text { attempts (2) }\end{array}$ & $\begin{array}{l}\text { Failed first three } \\
\text { attempts (3) }\end{array}$ \\
\hline & $(1)$ & $(2)$ & $(3)$ \\
\hline Int. Rate & $\begin{array}{c}0.002 * * * \\
(0.001)\end{array}$ & $\begin{array}{c}0.006 * * * \\
(0.001)\end{array}$ & $\begin{array}{c}0.012 * * * \\
(0.002)\end{array}$ \\
\hline Log(Loan Amnt) & $\begin{array}{c}0.000 \\
(0.002)\end{array}$ & $\begin{array}{c}0.012 * * * \\
(0.004)\end{array}$ & $\begin{array}{l}0.012 * \\
(0.007)\end{array}$ \\
\hline Log(Term) & $\begin{array}{c}0.040 * * * \\
(0.003)\end{array}$ & $\begin{array}{c}0.035 * * * \\
(0.006)\end{array}$ & $\begin{array}{c}0.033 * * * \\
(0.010)\end{array}$ \\
\hline Log(Word count) & $\begin{array}{c}-0.044 * * * \\
(0.003)\end{array}$ & $\begin{array}{c}-0.015 * * * \\
(0.006)\end{array}$ & $\begin{array}{l}-0.006 \\
(0.009)\end{array}$ \\
\hline Credit score & $\begin{array}{c}0.005 * * * \\
(0.000)\end{array}$ & $\begin{array}{c}0.005 * * * \\
(0.000)\end{array}$ & $\begin{array}{c}0.003 * * * \\
(0.000)\end{array}$ \\
\hline Education & $\begin{array}{c}-0.007 * * \\
(0.004)\end{array}$ & $\begin{array}{c}-0.014 * \\
(0.007)\end{array}$ & $\begin{array}{l}-0.008 \\
(0.012)\end{array}$ \\
\hline Log(Income) & $\begin{array}{c}0.000 \\
(0.002)\end{array}$ & $\begin{array}{c}-0.016 * * * \\
(0.005)\end{array}$ & $\begin{array}{c}0.001 \\
(0.008)\end{array}$ \\
\hline Female & $\begin{array}{c}-0.036^{* * * *} \\
(0.004)\end{array}$ & $\begin{array}{c}-0.027 * * * \\
(0.009)\end{array}$ & $\begin{array}{l}-0.012 \\
(0.015)\end{array}$ \\
\hline Log(EmpLength) & $\begin{array}{c}0.001 \\
(0.002)\end{array}$ & $\begin{array}{c}0.000 \\
(0.003)\end{array}$ & $\begin{array}{c}0.005 \\
(0.006)\end{array}$ \\
\hline Vehicle & $\begin{array}{c}0.038 * * * \\
(0.003)\end{array}$ & $\begin{array}{c}0.009 \\
(0.007)\end{array}$ & $\begin{array}{l}-0.004 \\
(0.012)\end{array}$ \\
\hline Marriage status & $\begin{array}{c}-0.008 * * \\
(0.003)\end{array}$ & $\begin{array}{c}0.003 \\
(0.007)\end{array}$ & $\begin{array}{c}-0.002 \\
(0.011)\end{array}$ \\
\hline Log(Age) & $\begin{array}{c}1.857 * * * \\
(0.192)\end{array}$ & $\begin{array}{c}1.123 * * \\
(0.446)\end{array}$ & $\begin{array}{c}0.792 \\
(0.774)\end{array}$ \\
\hline $\log \left(\mathrm{Age}^{2}\right)$ & $\begin{array}{c}-0.274 * * * \\
(0.028)\end{array}$ & $\begin{array}{c}-0.165^{* * * *} \\
(0.064)\end{array}$ & $\begin{array}{l}-0.120 \\
(0.112)\end{array}$ \\
\hline GDP growth & $\begin{array}{c}-0.003 * * * \\
(0.000)\end{array}$ & $\begin{array}{c}0.004 * * * \\
(0.001)\end{array}$ & $\begin{array}{c}0.003 \\
(0.002)\end{array}$ \\
\hline Inflation & $\begin{array}{c}0.012 * * * \\
(0.002)\end{array}$ & $\begin{array}{l}-0.001 \\
(0.005)\end{array}$ & $\begin{array}{c}0.002 \\
(0.009)\end{array}$ \\
\hline Tierlcities & $\begin{array}{c}-0.018 * * * \\
(0.003) \\
\end{array}$ & $\begin{array}{c}-0.019 * * * \\
(0.007) \\
\end{array}$ & $\begin{array}{l}-0.022 * \\
(0.011) \\
\end{array}$ \\
\hline Pseudo $R^{2}$ & 0.04 & 0.02 & 0.01 \\
\hline $\mathrm{N}$ & 93,720 & 25,089 & 9,696 \\
\hline
\end{tabular}

Note: This table reports the marginal effects estimated around mean points. Robust standard errors are in parentheses. Dependent variable is applied, equal to 1 if the borrower has submitted a loan application after experiencing earlier rejection(s) and zero otherwise. Int. Rate is the rate of interest in percentages (\%) that borrower is willing to pay. $\log (\operatorname{Loan} A m n t)$ is the log of loan amount requested by the borrower in thousand RMB. $\log ($ Term) is the log of loan maturity in months. $\log$ (Word count) is the log of word count of loan narrative posted by the borrower. Credit score is the credit score of the borrower (as of when the listing was created). Education equals to 1 if the borrower has at least a university degree. $\log$ (Income) is the log of monthly income of the borrower. Female equals to 1 if the borrower is female; 0 otherwise. $\log$ (EmpLength) is the log of work experience in number of years. Vehicle equals to 1 if the borrower has a car; 0 otherwise. Marriage status equals to 1 if the borrower is married; 0 otherwise. $\log (A g e)$ is the $\log$ of the age of borrower in years. $\log \left(\operatorname{Age}^{2}\right)$ is the $\log$ of borrower's age squared. GDP growth rate is annual growth rate of real provincial GDP in which the borrower is resident. Inflation is measured by consumer price index. Tierlcities equals to 1 if the borrower is living in a Tier 1 city; 0 otherwise. Column (1), (2) and (3) represents marginal effects results after borrowers failed first, first two and first three application, respectively. *,**,*** denote significance at the 10,5 and $1 \%$ level. 
Table 4. Lender's decision to approve a consumption loan or not

\begin{tabular}{|c|c|c|c|}
\hline & $\begin{array}{l}\text { Failed first attempt } \\
\text { (1) }\end{array}$ & $\begin{array}{l}\text { Failed first two attempts } \\
(2)\end{array}$ & $\begin{array}{l}\text { Failed first three attempts } \\
\text { (3) }\end{array}$ \\
\hline Int. Rate & $\begin{array}{c}-0.001 * * * \\
(0.000)\end{array}$ & $\begin{array}{c}-0.001 * * \\
(0.000)\end{array}$ & $\begin{array}{c}0.000 \\
(0.000)\end{array}$ \\
\hline $\log ($ Loan Amnt $)$ & $\begin{array}{c}-0.017 * * * \\
(0.001)\end{array}$ & $\begin{array}{c}-0.010^{* * *} \\
(0.001)\end{array}$ & $\begin{array}{c}-0.009 * * * \\
(0.002)\end{array}$ \\
\hline Log(Term) & $\begin{array}{c}0.006 * * * \\
(0.001)\end{array}$ & $\begin{array}{c}0.001 \\
(0.002)\end{array}$ & $\begin{array}{c}0.003 \\
(0.003)\end{array}$ \\
\hline Log(Word count) & $\begin{array}{c}0.001 \\
(0.001)\end{array}$ & $\begin{array}{c}0.002 \\
(0.002)\end{array}$ & $\begin{array}{c}0.001 \\
(0.003)\end{array}$ \\
\hline Credit score & $\begin{array}{c}0.001 * * * \\
(0.000)\end{array}$ & $\begin{array}{c}0.001 * * * \\
(0.000)\end{array}$ & $\begin{array}{c}0.000 * * * \\
(0.000)\end{array}$ \\
\hline $\begin{array}{l}\text { Log(Time } \\
\text { interval) }\end{array}$ & $\begin{array}{c}0.002 * * * \\
(0.000)\end{array}$ & $\begin{array}{c}0.002 * * * \\
(0.001)\end{array}$ & $\begin{array}{c}0.003 * * * \\
(0.001)\end{array}$ \\
\hline Education & $\begin{array}{c}0.003 * * \\
(0.002)\end{array}$ & $\begin{array}{c}0.001 \\
(0.002)\end{array}$ & $\begin{array}{l}0.003 \\
(0.003)\end{array}$ \\
\hline Log(Income) & $\begin{array}{c}0.004 * * * \\
(0.001)\end{array}$ & $\begin{array}{l}0.003^{* * *} \\
(0.002)\end{array}$ & $\begin{array}{l}0.004^{*} \\
(0.002)\end{array}$ \\
\hline Female & $\begin{array}{c}0.001 \\
(0.002)\end{array}$ & $\begin{array}{c}0.002 \\
(0.003)\end{array}$ & $\begin{array}{c}0.004 \\
(0.003)\end{array}$ \\
\hline Log(EmpLength) & $\begin{array}{c}0.001 \\
(0.001)\end{array}$ & $\begin{array}{l}0.002 * * \\
(0.001)\end{array}$ & $\begin{array}{c}0.000 \\
(0.001)\end{array}$ \\
\hline Vehicle & $\begin{array}{l}-0.003 * \\
(0.002)\end{array}$ & $\begin{array}{l}-0.004^{*} \\
(0.003)\end{array}$ & $\begin{array}{l}-0.004 \\
(0.003)\end{array}$ \\
\hline Marriage status & $\begin{array}{c}0.000 \\
(0.002)\end{array}$ & $\begin{array}{c}0.000 \\
(0.002)\end{array}$ & $\begin{array}{c}0.001 \\
(0.003)\end{array}$ \\
\hline Log(Age) & $\begin{array}{l}-0.054 \\
(0.111)\end{array}$ & $\begin{array}{c}0.366^{* *} \\
(0.167)\end{array}$ & $\begin{array}{c}0.132 \\
(0.195)\end{array}$ \\
\hline $\log \left(\mathrm{Age}^{2}\right)$ & $\begin{array}{c}0.010 \\
(0.016)\end{array}$ & $\begin{array}{c}-0.053 * * \\
(0.024)\end{array}$ & $\begin{array}{l}-0.018 \\
(0.028)\end{array}$ \\
\hline GDP growth & $\begin{array}{l}0.000^{*} \\
(0.000)\end{array}$ & $\begin{array}{c}0.000 \\
(0.000)\end{array}$ & $\begin{array}{l}0.000 \\
(0.000)\end{array}$ \\
\hline Inflation & $\begin{array}{c}-0.003 * * * \\
(0.001)\end{array}$ & $\begin{array}{l}-0.002 \\
(0.002)\end{array}$ & $\begin{array}{l}-0.002 \\
(0.002)\end{array}$ \\
\hline Tier 1 cities & $\begin{array}{c}0.001 \\
(0.002) \\
\end{array}$ & $\begin{array}{c}0.001 \\
(0.002)\end{array}$ & $\begin{array}{c}0.000 \\
(0.003)\end{array}$ \\
\hline Pseudo $R^{2}$ & 0.66 & 0.63 & 0.59 \\
\hline $\mathrm{N}$ & 25,888 & 9,868 & 4,314 \\
\hline
\end{tabular}

Note: This table reports the marginal effects estimated around mean points. Robust standard errors are in parentheses. Dependent variable is Approved, equal to 1 if lenders approve the application; zero otherwise. Int. Rate is the rate of interest in percentages (\%) that borrower is willing to pay. $\log (\operatorname{Loan} A m n t)$ is the log of loan amount requested by the borrower in thousand RMB. $\log ($ Term) is the log of loan maturity in months. $\log$ (Word count) is the log of word count of loan narrative posted by the borrower. Credit score is the credit score of the borrower (as of when the listing was created). $\log$ (Time interval) is the log of time (in days) between the initial loan rejection and the borrower's next funding application. Education equals to 1 if the borrower has at least a university degree. $\log$ (Income) is the log of monthly income of the borrower. Female equals to 1 if the borrower is female; 0 otherwise. $\log$ (EmpLength) is the log of work experience in number of years. Vehicle equals to 1 if the borrower has a car; 0 otherwise. Marriage status equals to 1 if the borrower is married; 0 otherwise. $\log (\operatorname{Age})$ is the $\log$ of the age of borrower in years. $\log \left(\mathrm{Age}^{2}\right)$ is the $\log$ of borrower's age squared. GDP growth is annual growth rate of real provincial GDP in which the borrower is resident. Inflation is measured by consumer price index. Tierlcities equals to 1 if the borrower is living in a Tier 1 city; 0 otherwise. Column (1), (2) and (3) represents marginal effects results after borrowers failed first, first two and first three application, respectively. *, **,*** denote significance at the 10,5 and $1 \%$ level. 
Table 5. Lenders decision to approve or not (At least four applications).

\begin{tabular}{|c|c|c|c|}
\hline & $(1)$ & (2) & (3) \\
\hline Int. Rate & $\begin{array}{c}-0.003 * * * \\
(0.000)\end{array}$ & $\begin{array}{c}-0.003 * * * \\
(0.000)\end{array}$ & $\begin{array}{c}-0.003 * * * \\
(0.000)\end{array}$ \\
\hline Log(Loan Amnt) & $\begin{array}{c}-0.025^{* * *} \\
(0.001)\end{array}$ & $\begin{array}{c}-0.025 * * * \\
(0.001)\end{array}$ & $\begin{array}{c}-0.025 * * * \\
(0.001)\end{array}$ \\
\hline $\log ($ Term $)$ & $\begin{array}{c}-0.008^{* * *} \\
(0.002)\end{array}$ & $\begin{array}{c}-0.008 * * * \\
(0.002)\end{array}$ & $\begin{array}{c}-0.007 * * * \\
(0.002)\end{array}$ \\
\hline $\log ($ Word count $)$ & $\begin{array}{c}0.006 * * * \\
(0.002)\end{array}$ & $\begin{array}{l}0.004^{*} \\
(0.002)\end{array}$ & $\begin{array}{c}0.005^{* *} \\
(0.002)\end{array}$ \\
\hline Credit score & $\begin{array}{c}0.001 * * * \\
(0.000)\end{array}$ & $\begin{array}{c}0.001 * * * \\
(0.000)\end{array}$ & $\begin{array}{c}0.001 * * * \\
(0.000)\end{array}$ \\
\hline Log(Time interval) & $\begin{array}{c}0.008 * * * \\
(0.001)\end{array}$ & $\begin{array}{c}0.007 * * * \\
(0.001)\end{array}$ & $\begin{array}{c}0.007 * * * \\
(0.001)\end{array}$ \\
\hline Education & $\begin{array}{c}0.000 \\
(0.003)\end{array}$ & $\begin{array}{c}0.002 \\
(0.003)\end{array}$ & $\begin{array}{c}0.001 \\
(0.003)\end{array}$ \\
\hline Log(Income) & $\begin{array}{c}0.007 * * * \\
(0.002)\end{array}$ & $\begin{array}{c}0.008 * * * \\
(0.002)\end{array}$ & $\begin{array}{c}0.007 * * * \\
(0.002)\end{array}$ \\
\hline Female & $\begin{array}{c}0.009 * * * \\
(0.003)\end{array}$ & $\begin{array}{c}0.009 * * * \\
(0.003)\end{array}$ & $\begin{array}{c}0.009^{* * *} \\
(0.001)\end{array}$ \\
\hline Log(EmpLength) & $\begin{array}{c}0.000 \\
(0.001)\end{array}$ & $\begin{array}{c}0.001 \\
(0.001)\end{array}$ & $\begin{array}{c}0.001 \\
(0.001)\end{array}$ \\
\hline Vehicle & $\begin{array}{l}-0.006^{*} \\
(0.003)\end{array}$ & $\begin{array}{c}-0.006 * * \\
(0.003)\end{array}$ & $\begin{array}{c}-0.006^{* *} \\
(0.003)\end{array}$ \\
\hline Marriage status & $\begin{array}{c}0.004 \\
(0.002)\end{array}$ & $\begin{array}{c}0.002 \\
(0.002)\end{array}$ & $\begin{array}{c}0.003 \\
(0.002)\end{array}$ \\
\hline Log(Age) & $\begin{array}{c}0.829 * * * \\
(0.210)\end{array}$ & $\begin{array}{c}0.616^{* * *} \\
(0.203)\end{array}$ & $\begin{array}{c}0.673 * * * \\
(0.204)\end{array}$ \\
\hline $\log \left(\mathrm{Age}^{2}\right)$ & $\begin{array}{c}-0.116^{* * * *} \\
(0.031)\end{array}$ & $\begin{array}{c}-0.086 * * * \\
(0.030)\end{array}$ & $\begin{array}{c}-0.094 * * * \\
(0.030)\end{array}$ \\
\hline GDP growth & $\begin{array}{c}0.001 * * * \\
(0.000)\end{array}$ & $\begin{array}{c}0.001 * * * \\
(0.000)\end{array}$ & $\begin{array}{c}0.001 * * \\
(0.000)\end{array}$ \\
\hline Inflation & $\begin{array}{c}0.006 * * * \\
(0.001)\end{array}$ & $\begin{array}{c}0.006 * * * \\
(0.001)\end{array}$ & $\begin{array}{c}0.006 * * * \\
(0.001)\end{array}$ \\
\hline Tier1cities & $\begin{array}{c}0.001 \\
(0.003)\end{array}$ & $\begin{array}{c}0.002 \\
(0.003)\end{array}$ & $\begin{array}{c}0.002 \\
(0.003)\end{array}$ \\
\hline Number of previous fails & $\begin{array}{c}-0.007 * * * \\
(0.001)\end{array}$ & - & $\begin{array}{c}-0.003 * * * \\
(0.001)\end{array}$ \\
\hline Previous success rate & & $\begin{array}{c}0.041 * * * \\
(0.004)\end{array}$ & $\begin{array}{c}0.033^{* * *} \\
(0.005) \\
\end{array}$ \\
\hline Pseudo $R^{2}$ & 0.66 & 0.66 & 0.66 \\
\hline $\mathrm{N}$ & 20,631 & 20,631 & 20,631 \\
\hline
\end{tabular}

Note: This table reports the marginal effects estimated around mean points. Robust standard errors are in parentheses. Dependent variable is Approved, equal to 1 if lenders approve the application; zero otherwise. Number of previous fails is the cumulative number of previous rejections. Previous success rate is the cumulative success rate of previous applications. All other variables are defined in notes to Table $4 . *, * *, * * *$ denote significance at the 10,5 and $1 \%$ level. 
Table 6: Propensity score matching

\begin{tabular}{|c|c|c|c|}
\hline \multicolumn{4}{|c|}{ Panel A: Borrowers' decision to apply or not } \\
\hline & Failed first attempt (1) & Failed first two attempts (2) & Failed first three attempts (3) \\
\hline & $(1)$ & $(2)$ & $(3)$ \\
\hline Female & $\begin{array}{c}-0.035 * * * \\
(0.006)\end{array}$ & $\begin{array}{c}-0.022 * * * \\
(0.013)\end{array}$ & $\begin{array}{c}0.004 \\
(0.022)\end{array}$ \\
\hline Matched N & 27,668 & 6,560 & 2,406 \\
\hline
\end{tabular}

Panel B: Lenders' decision to approve or not

\begin{tabular}{lccc}
\hline & Failed first attempt (1) & Failed first two attempts (2) & Failed first three attempts (3) \\
\hline Female & $(1)$ & $(2)$ & $(3)$ \\
& 0.006 & $0.013^{* * *}$ & $0.010^{* *}$ \\
& $(0.004)$ & $(0.004)$ & $(0.004)$ \\
\hline Matched N & 6,776 & 2,456 & 1,048 \\
\hline
\end{tabular}

Note: In this table, we report the average treatment effects of Female (the treatment) on borrowers' decision to apply or not in Panel A and on lenders' decision to approve or not in Panel B. In Panel A, the dependent variable is applied $(=1$ if the borrower has submitted a loan application after experiencing earlier rejection(s); zero otherwise). In Panel B, the dependent variable is approved, equal to 1 if lenders approve the application; zero otherwise. We include all the variables on loan terms and borrower characteristics. Int. Rate is the rate of interest in percentages (\%) that borrower is willing to pay. $\log (\operatorname{Loan} A m n t)$ is the log of loan amount requested by the borrower in thousand RMB. $\log ($ Term) is the log of loan maturity in months. $\log$ (Word count) is the log of word count of loan narrative posted by the borrower. Credit score is the credit score of the borrower (as of when the listing was created). Education equals to 1 if the borrower has at least a university degree. $\log ($ Income) is the log of monthly income of the borrower. Female equals to 1 if the borrower is female; 0 otherwise. $\log ($ EmpLength) is the $\log$ of work experience in number of years. Vehicle equals to 1 if the borrower has a car; 0 otherwise. Marriage status equals to 1 if the borrower is married; 0 otherwise. $\log (A g e)$ is the log of the age of borrower in years. $\log \left(A g e^{2}\right)$ is the log of borrower's age squared. GDP growth is annual growth rate of real provincial GDP in which the borrower is resident. Inflation is measured by consumer price index. Tierlcities equals to 1 if the borrower is living in a Tier 1 city; 0 otherwise. Column (1), (2) and (3) represents marginal effects results after borrowers failed first, first two and first three application, respectively. *, **, *** denote significance at the 10, 5 and $1 \%$ level. 
Table 7: Borrower's decision to apply for a loan or not, controlling for the types of loans.

\begin{tabular}{lccc}
\hline & $\begin{array}{c}\text { Failed first } \\
\text { attempt (1) }\end{array}$ & $\begin{array}{c}\text { Failed first two } \\
\text { attempts }(2)\end{array}$ & $\begin{array}{c}\text { Failed first three } \\
\text { attempts (3) }\end{array}$ \\
\hline Loan purpose: car purchase & $(1)$ & $(2)$ & $(3)$ \\
& $0.020^{* * *}$ & -0.009 & -0.025 \\
Loan purpose: education & $(0.005)$ & $(0.011)$ & $(0.018)$ \\
Loan purpose: home & 0.004 & 0.017 & $-0.067^{* *}$ \\
refurbishment & $(0.008)$ & $(0.020)$ & $(0.033)$ \\
Loan purpose: housing & $0.034^{* * *}$ & -0.002 & $-0.026^{*}$ \\
& $(0.004)$ & $(0.009)$ & $(0.014)$ \\
Loan purpose: wedding & -0.006 & -0.014 & $-0.044^{*}$ \\
& $(0.006)$ & $(0.014)$ & $(0.024)$ \\
\hline Pseudo $R^{2}$ & $0.030^{* * *}$ & 0.006 & -0.014 \\
$\mathrm{~N}$ & $(0.007)$ & $(0.015)$ & $(0.025)$ \\
\hline
\end{tabular}

Note: This table reports the marginal effects estimated around mean points. Robust standard errors are in parentheses. Dependent variable is applied, equal to 1 if the borrower has submitted a loan application after experiencing earlier rejection(s) and zero otherwise. Int. Rate is the rate of interest in percentages (\%) that borrower is willing to pay. $\log (\operatorname{Loan} A m n t)$ is the log of loan amount requested by the borrower in thousand RMB. $\log ($ Term) is the log of loan maturity in months. $\log$ (Word count) is the log of word count of loan narrative posted by the borrower. Credit score is the credit score of the borrower (as of when the listing was created). Education equals to 1 if the borrower has at least a university degree. $\log$ (Income) is the log of monthly income of the borrower. Female equals to 1 if the borrower is female; 0 otherwise. $\log$ (EmpLength) is the log of work experience in number of years. Vehicle equals to 1 if the borrower has a car; 0 otherwise. Marriage status equals to 1 if the borrower is married; 0 otherwise. $\log (\mathrm{Age})$ is the $\log$ of the age of borrower in years. $\log \left(\operatorname{Age}^{2}\right)$ is the $\log$ of borrower's age squared. Loan purpose dummies include: Car purchase $(=1$ if loan is requested for car purchasing; 0 otherwise), Education ( $=1$ if loan is requested for education; 0 otherwise), Home refurbishment ( $=1$ if loan is requested for the use of home refurbishment; 0 otherwise), Housing ( $=1$ if loan is requested for housing; 0 otherwise), Personal expenditure ( $=1$ if loan is requested for personal expenditure; 0 otherwise) and Wedding (=1 if loan is requested for wedding expenses; 0 otherwise). GDP growth rate is annual growth rate of real provincial GDP in which the borrower is resident. Inflation is measured by consumer price index. Tierlcities equals to 1 if the borrower is living in a Tier 1 city; 0 otherwise. Column (1), (2) and (3) represents marginal effects results after borrowers failed first, first two and first three application, respectively. *,**,*** denote significance at the 10,5 and $1 \%$ level. 